\title{
UTWORZENIE FEDERALNEJ SŁUŻBY GWARDII NARODOWEJ JAKO DOWÓD FSB-FIKACJI WŁADZY W FEDERACJI ROSYJSKIEJ
}

\author{
ESTABLISHMENT OF THE FEDERAL NATIONAL GUARD \\ TROOPS SERVICE OF THE RUSSIAN FEDERATION \\ AS A EVIDENCE OF EVOLUTIONARY FSB-FICATION \\ OF POWER IN RUSSIA
}

Justyna Doroszczyk*

\begin{abstract}
ABSTRAKT
Artykuł poświęcony jest analizie kompetencji, funkcji oraz politycznego potencjału utworzonej w 2016 roku Federalnej Służby Gwardii Narodowej Federacji Rosyjskiej. Powstanie nowej specsłużby jest konceptualizowane jako sformalizowany przykład ewolucyjnej FSB-fikacji władzy w Rosji. Analizowany w artykule casus utworzenia Federalnej Służby Gwardii Narodowej wpisuje się w rosyjską tradycję służb specjalnych jako strategicznego narzędzia zabezpieczającego reżim przed potencjalną destabilizacją w perspektywie elekcji prezydenckiej w 2018 roku.
\end{abstract}

Słowa kluczowe: służby specjalne, FSB, rosgwardia, Putin, federalna służba gwardii narodowej
The article is devoted to the analysis of the competence, functions and political potential of the Federal National Guard Troops Service of the Russian Federation, established in 2016. The creation of a new formation of secret service is conceptualized as a formalized example of evolutionary "fsb-fication" of power in Russian Federation. Casus of establishment of the Federal National Guard Troops Service of the Russian Federation, which is analyzed in the article, is presented as a part of the tradition of the Russian special services as a strategic tool for protecting the regime in order to manage with potential destabilization due to the presidential election in 2018.

Keywords: secret services, fsb, Russian Guards, Putin, National Guard of Russia

* Polska Akademia Nauk, Instytut Filozofii i Socjologii. 
Współczesna Federacja Rosyjska to państwo o stosunkowo długiej i rozbudowanej tradycji służb specjalnych, których autorytet jest wykorzystywany do legitymizacji funkcjonującego reżimu politycznego, jak również ochrony jego stabilności oraz unikatowej tkanki społeczeństwa rosyjskiego przed destrukcyjnymi wpływami z zewnątrz - „Nie-Rosji”, wrogiego, zdegenerowanego Zachodu. Elementem zasadniczym, warunkującym funkcjonowanie władzy w Rosji, jest niewątpliwie specyficzna kultura polityczna, której rdzeń stanowi wertykalizm oraz centralizacja struktury władzy, która jest intepretowana jako zgodna z tradycją rosyjskiej państwowości.

Przedmiotem artykułu jest proces FSB-fikacji władzy w Federacji Rosyjskiej po objęciu władzy prezydenckiej przez Władimira Putina. Główną tezą artykułu jest przekonanie, iż rozszerzenie kompetencji i reorganizacja struktur siłowych, której najbardziej aktualną manifestacją jest utworzenie Federalnej Służby Gwardii Narodowej, stanowi jedną z formalnych egzemplifikacji rozłożonego w czasie procesu przejmowania ważnych stanowisk państwowych przez osoby wywodzące się z siłowików $w^{1}$. Celem artykułu jest analiza kompetencji i podstawowych funkcji, politycznego potencjału utworzonej w 2016 roku Federalnej Służby Gwardii Narodowej Federacji Rosyjskiej. Innym celem artykułu jest identyfikacja i konceptualizacja potencjału utworzenia nowej struktury bezpieczeństwa państwowego w procesie FSB-fikacji władzy w Rosji. Powstanie nowej specsłużby jest sformalizowanym przykładem ewolucyjnej FSB-fikacji władzy w Rosji oraz znamionuje eskalację czynnika bezpieczeństwa w rosyjskim dyskursie politycznym. Analizowany w artykule casus utworzenia Federalnej Służby Gwardii Narodowej jest integralnym elementem wpisanym w rosyjską tradycję służb specjalnych jako strategicznego narzędzia zabezpieczającego reżim przed potencjalną destabilizacją w perspektywie elekcji prezydenckiej w 2018 roku. Głównymi metodami służącymi realizacji celu badawczego oraz udowodnieniu tezy są: analiza rosyjskojęzycznych aktów prawnych, dekretów prezydenckich oraz dokumentów regulujących funkcjonowanie oraz określających kompetencje nowo powstałej Federalnej Służby Gwardii Narodowej w kontekście zacieśniania związków między władzą państwową a środowiskiem służb specjalnych.

Sprawowanie władzy poprzez tzw. odgórne reformowanie, z wyłączeniem konsultacji ze społeczeństwem, to cecha systemów autorytarnych z dominującą pozycją środowisk siłowych. Wraz z początkiem prezydentury Władimira Putina

${ }^{1} \mathrm{~W}$ polskojęzycznej literaturze najczęściej spotykane jest określenie siłownicy. W artykule występuje określenie siłowicy, wywodzące się z tłumaczenia rosyjskiego słowa silowiki. 
(od 2000 roku) główną podstawę, bazę konsolidującą reżim stanowi środowisko służb specjalnych, tzw. siłowików. Jak zauważa Marek Menkiszak (2015), to właśnie światopogląd, mentalność oraz interesy przedstawicieli środowiska siłowików (osób związanych ze środowiskiem służb specjalnych) determinują charakter wewnętrznej, jak i zagranicznej polityki Federacji Rosyjskiej. Obecność siłowików na wysokich stanowiskach państwowych uzasadnia oraz racjonalizuje autorytarny model władzy - swoistą, uwarunkowaną specyfiką tradycji rosyjskiej państwowości, putinokrację.

Według Borogan i Sołdatowa (2010) kluczowa jest siła politycznego oddziaływania środowisk siłowych. Siłowicy są określani mianem nowej rosyjskiej szlachty i z tego względu uzurpują sobie szczególne miejsce w społeczeństwie rosyjskim. Dominacja siłowików w najbliższym otoczeniu prezydenta, a także ukonstytuowanie się prestiżu politycznego służb specjalnych stanowi jedną z legitymizacji konfrontacyjnej, antyzachodniej polityki i retoryki Władimira Putina, której nacjonalistyczny, izolacyjny, konserwatywny wariant charakteryzuje dynamikę zmian dyskursu politycznego w Rosji od 2012 roku. Nie bez znaczenia dla problematyzacji fenomenu FSB-fikacji władzy w Rosji jest osobista relacja łącząca Władimira Putina ze środowiskiem służb specjalnych. Putina i siłowików łączy wspólnota światopoglądowa, jak również wizja świata oraz kondycji Rosji jako wyjątkowej cywilizacji otoczonej przez agresywny Zachód, skłonny do nieusankcjonowanych ingerencji w sprawy wewnętrzne państw wywodzących się spoza kręgu cywilizacji europejskiej.

Silna pozycja służb specjalnych jako głównego zaplecza informacyjnego prezydenta Federacji Rosyjskiej eksplikuje i jednocześnie uzasadnia antyzachodni wariant myślenia geopolitycznego władzy na Kremlu, w optyce której głównym, odmiennie zaprogramowanym pod względem kulturowym wrogiem jest Zachód - antyteza Rosji i rosyjskiej tradycji państwa „porządku” - który dąży do osłabienia potencjału Rosji na arenie międzynarodowej, jak również destabilizacji wewnętrznej rosyjskiego systemu politycznego.

Identyfikacja roli specsłużb jako istotnej siły politycznej sprzyja kreacji wizerunku Rosji jako państwa, w którym faktyczną władzę sprawuje korporacja Federalnej Służby Bezpieczeństwa, która nie jest zwyczajną agencją państwową, gdyż łączy w sobie funkcje policji politycznej z zadaniami agencji wywiadowczej. Ponadto wartość siłowików jako istotnego zaplecza władzy prezydenckiej podnosi zdeklarowane otwarte poparcie dla koncepcji silnej, scentralizowanej państwowości. W kontekście legitymizacji wizji Rosji Putina jako odrębnej jakości kulturowo-politycznej, realizującej projekt suwerennej - uwzględniającej 
specyfikę warunków rosyjskich - demokracji, dominujące wśród przedstawicieli środowisk siłowych przekonanie, zgodnie z którym władza powinna zachować kontrolę nad obszarami państwa o strategicznym znaczeniu, zwiększa prawdopodobieństwo poszerzania zakresu kompetencji specsłużb oraz uzasadnia możliwości tworzenia nowych struktur siłowych odpowiedzialnych za bezpieczeństwo wewnętrzne Federacji Rosyjskiej. Faworyzowanie działań środowisk siłowych, apologia wertykalnego modelu władzy oraz potencjału idei silnego państwa stanowi integralną część rosyjskiej tradycji polityczno-kulturowej, której wartość determinującą stanowi samodzierżawie oraz tradycja specsłużb jako filaru stabilizacji systemu politycznego w Rosji.

W kontekście prywatyzacji władzy w Rosji przez Federalną Służbę Bezpieczeństwa (FSB) - spadkobierczynię organizacji - matki Komitetu Bezpieczeństwa Państwowego (KGB), rozwiązanego w 1991 roku, można sproblematyzować jako FSB-fikację władzy w państwie o tradycjach wertykalnych. FSB-fikacja jest przejawem wzrostu autorytetu polityczno-ideologicznego służb specjalnych, co sprzyja konsolidacji negatywnej percepcji wartości identyfikowanych z Zachodem, które jawią się jako wrogie, sprzeczne z rosyjską kulturą polityczną, jej odmiennym, uniaktowym kodem cywilizacyjno-kulturowym oraz tradycją państwowości, lecz przede wszystkim czyni z prezydenta Federacji Rosyjskiej zakładnika informacji dostarczanych przez zaufane kręgi środowisk siłowych, które stanowią obecnie główne zaplecze informacyjne gospodarza Kremla. Federalna Służba Bezpieczeństwa - najpotężniejsza sukcesorka KGB - zawdzięcza swoje wysokie wpływy protekcji samego prezydenta Putina. Warto podkreślić, iż jeden z priorytetów politycznych Władimira Putina jako prezydenta Federacji Rosyjskiej stanowiła i stanowi rehabilitacja prestiżu służb specjalnych.

W kontekście putinowskiej retoryki konfrontacyjnej, zorientowanej na akcentowanie wrogości między Zachodem a Rosją, działalność służb specjalnych jest zorientowana na zwalczanie lub neutralizowanie wrogów Rosji, jak również ochronę rosyjskiego interesu narodowego przed hegemonicznym, unifikującym wpływem Zachodu - odwiecznego wroga Rosji. Konspirologiczna wizja świata zewnętrznego wspierana przez środowisko służb specjalnych odpowiada ideologicznej orientacji antyzachodniej retoryki Władimira Putina, której bazę stanowi definiowanie cywilizacyjnej, politycznej i kulturowej jedni oraz unikatowości tzw. rosyjskiego świata, który stanowi antytezę zaprogramowango na indywidualizm, realizującego idee liberalnej demokracji Zachodu. Istotną uwagę, rzucającą nowe światło na proces FSB-fikacji władzy, czyni A.W. Fokina (2014). Według Fokiny (2014) obecność czynnika cywilizacyjnego w myśleniu 
rosyjskim stanowi przyczynek do dyskusji o wartości i kondycji cywilizacji rosyjskiej.

Wykorzystanie potencjału służb specjalnych do przeciwdziałania infoagresji Zachodu, utożsamianej z promocją „obcej” tradycji rosyjskiej demokracji liberalnej. Siergiej Tkaczenko (2011) w swojej książce pt. Informacjonnaja wojna protiw Rossiji interpretuje wzmocnienie autorytetu specsłużb jako manewr ubezpieczający nie tylko stabilność reżimu Władimira Putina, lecz przede wszystkim jest to - jego zdaniem zabieg sprzęgnięty z koncepcją izolacjonistycznej, nacjonalistycznej oraz antyzachodniej retoryki władzy na Kremlu. Służby specjalne w okresie drugiej prezydentury Władimira Putina ewolucyjnie umacniają swój autorytet polityczny jako ugrupowanie, które jest gotowe do decydującej i ostatecznej walki o zachowanie statusu siły o znacznym potencjale oddziaływania na sprawowanie władzy w Federacji Rosyjskiej. Niemniej jednak ofensywa polityczna FSB nie jest zjawiskiem nowym. Jak słusznie zauważa Bettina Renz (2007), proces klarowania charakteru Federalnej Służby Bezpieczeństwa jako struktury zaangażowanej w sprawy polityczne zapoczątkowało objęcie fotela prezydenckiego przez Władimira Putina w 2000 roku. Obecne dążenie służb do pozyskania, jak również utrzymania wpływów politycznych jest zjawiskiem bezprecedensowym, a lojalność środowiska siłowików stanowi bazowy element fortyfikacji reżimu putinowskiego na wypadek potencjalnego przewrotu.

Zarządzanie państwem poprzez wzmocnienie wpływów korporacji służb specjalnych, rozszerzenie służbowych prerogatyw oraz kompetencji wpisuje się w rosyjską tradycję uzasadniania prawomocności rosyjskiego systemu władzy przez wykorzystanie resortów siłowych jako kuźni kadr gwarantujących nienaruszalność reżimu politycznego z silną, dominującą pozycją prezydenta. W celu stabilizacji systemu Putin dokonuje szeregu manewrów reorganizujących służby bezpieczeństwa jako zaplecza asekurującego deklaratywne poparcie koncepcji silnej, wertykalnej władzy.

Ponadto fenomen FSB-fikacji władzy w Rosji jest zjawiskiem uwarunkowanym osobistymi relacjami łączącymi Władimira Putina ze środowiskiem specsłużb. Obejmując fotel prezydencki, Władimir Putin zdefiniował się jako produkt procesów kształtowania mentalności, sposobów interpretacji i konceptualizacji świata, w tym środowiska międzynarodowego w kategoriach „swój - My” - „oni” wróg - Zachód”, którym był poddawany podczas służby w komunistycznym KGB. Binarna percepcja rzeczywistości implikuje konieczność istnienia niepoprawnego moralnie wroga, zagrażającego integralności i suwerenności Rosji. Przed wrogim, destrukcyjnym wpływem zachodniego 
antagonisty rosyjskości, Rosja powinna chronić swoją cywilizacyjną specyfikę oraz izolować esencję narodu rosyjskiego, rosyjskiej kultury przed importowanymi z Zachodu ideałami liberalnej demokracji oraz dezintegrującym więzy wspólnotowe indywidualizmem.

Zgodnie z analizą dla Stratfor autorstwa Eugene Chałsowskiego (2015) tradycja antagonizacji Rosji wobec Zachodu jest integralną częścią rosyjskiego kodu kulturowego i elementem odwiecznego konfliktu cywilizacyjno-kulturowego między Rosją i Zachodem, którego współczesne oblicze wzmacnia autorytet i polityczny potencjał służb specjalnych, a zatem oddziałuje ona na percepcję rzeczywistości wobec Rosji zewnętrznej.

Polityczny potencjał specsłużb jest filarem integralności reżimu Władimira Putina. W perspektywie obrony stabilizacji systemu polityczna operatywność służb specjalnych jest skoncentrowana na efektywnej fortyfikacji rosyjskiej suwerenności. Reżim putinowski wykorzystuje lojalność zaufanych funkcjonariuszy środowisk siłowych, których orientacja ideologiczna jest komplementarna $\mathrm{z}$ antyzachodnią, binarną retoryką Władimira Putina, a w konsekwencji stanowi filar bezpieczeństwa i nienaruszalności rosyjskiego porządku systemowego. W celu zagwarantowania stałego poparcia ze strony służb specjalnych rosyjski prezydent w lipcu 2016 roku zainicjował proces wymiany starych, zasłużonych kadr na nowych lojalnych obrońców reżimu. Obsadzenie najważniejszych, kluczowych stanowisk w państwie lojalnymi pracownikami związanymi ze służbami specjalnymi, bądź wywodzącymi się ze środowiska specsłużb gwarantuje utrzymanie zaplecza konsolidacyjnego reżimu w postaci wsparcia ze strony zaufanych siłowików, funkcjonariuszy FSB, której - jak podkreśla Sakwa (2008) w uzasadnionych okolicznościach podporządkowane jest działanie instytucji egzekwujących prawo oraz agencji wywiadowczych. Według analizy Stratfor (2008) główna służba Federacji Rosyjskiej - Federalna Służba Bezpieczeństwa jest służbą-parasolem koordynującym działalność innych agencji, a tym samym jawi się jako siła monopolizująca rosyjskie środowisko służb odpowiedzialnych za bezpieczeństwo.

Sformalizowaną manifestacją zakorzenionego w rosyjskiej kulturze politycznej paradygmatu oddziaływania przedstawicieli środowisk służb specjalnych na decyzje polityczne w Rosji jest utworzenie Federalnej Służby Gwardii Narodowej - nowej specsłużby bezpośrednio podległej prezydentowi Federacji Rosyjskiej - oraz zaplanowane na 2018 rok powołanie Ministerstwa Bezpieczeństwa Państwowego. Tak poważna reorganizacja stanowi przesłankę uszczelniania systemu bezpieczeństwa Rosji w obliczu potencjalnej destabilizacji zarówno 
w wymiarze militarnym, jak i ideologicznym, gdyż utworzone struktury stanowią pas transmisyjny antyzachodniej, neoimperialnej, konserwatywnej ideologii, której zadaniem jest kreacja i eksport wizerunku Rosji jako unikatowej, samoistnej jedni cywilizacyjnej o odmiennym od zachodniego kodzie cywilizacyjno-kulturowym oraz typie mentalnościowym; jego cechą definiującą jest szacunek względem tradycji oraz wartości religijnych prawosławia, identyfikowanych jako ostoja i źródło rosyjskości. Nie podlega kwestii fakt, iż w sferze ideowej autorytet rosyjskich służb bezpieczeństwa sprzyja kreacji wizerunku Rosji jako doskonalszej moralnie cywilizacji, przy jednoczesnym akcentowaniu moralnej „zgnilizny” świata zachodniego. Aktywność kręgów rosyjskich siłowików jest zorientowana na intensyfikację wpływu służb na decyzje polityczne w Federacji Rosyjskiej, jak również koncentruje się na umacnianiu antyzachodniej, konspirologicznej retoryki Władimira Putina. Warto zwrócić uwagę na słuszną konstatację Kariny Orłowej (2016). Według rosyjskiej badaczki w perspektywie dyskursu antyzachodnio-konspirologicznego postulat przekształcenia Federalnej Służby Bezpieczeństwa w Ministerstwo Bezpieczeństwa Państwowego, jak również utworzenie Federalnej Służby Gwardii Narodowej stanowi uzasadnioną przesłankę do reewaluacji operatywności służb specjalnych jako struktur dysponujących znacznym potencjałem politycznym, zarówno w sytuacji pokoju, jak i w warunkach reżimowej entropii oraz wojny informacyjnej.

Utworzenie Federalnej Służby Gwardii Narodowej (ros. Rosgwardia) stanowi jeden z pierwszych sformalizowanych efektów inicjowanych przez Władimir Putina zabiegów reorganizacyjnych służb zorientowanych na zabezpieczenie podstaw stabilności i integralności systemu, jak również świadczy na rzecz tezy o nieustannej aktywności stylu myślenia o państwie i polityce rosyjskiej jako o sferze zmonopolizowanej przez środowisko związane ze służbami specjalnymi.

Ujawnienie politycznych aspiracji FSB, próby wybicia się na niezależność względem ośrodka władzy, stanowi jedno z istotnych wyzwań dla realizacji paradygmatu stabilizacji i centralizacji władzy Władimira Putina, który w celu umocnienia władzy na mocy dekretu nr 157 z 5 kwietnia 2016 „Woprosy Federalnoj Sluzby Woisk Nacjoalnoj Gwardii Rossijskoj Fiederacji” dokonał przekształcenia pionu wojsk wewnętrznych Ministerstwa Spraw Wewnętrznych i utworzył bezpośrednio podległą prezydentowi Federacji Rosyjskiej Gwardię Narodową (Rosgwardię). Istotnym, a zarazem jednym z głównych motywów utworzenia specsłużby podległej bezpośrednio prezydentowi Federacji Rosyjskiej jest nie tylko fortyfikcja putinowskiego monopolu na władzę na wypadek puczu, 
lecz przede wszystkim osiągnięcie pełnego podporządkowania służb władzy prezydenckiej. Jednym z motywów zabezpieczania legitymizacji wertykalizmu afirmowanego dotychczas przez środowisko siłowików jest utworzenie Federalnej Służby Gwardii Narodowej w kwietniu 2016 roku. Według Żochowskiego (2016) powołanie nowej struktury siłowej jest istotną ewolucją w procesie restrukturyzacji systemu instytucji bezpieczeństwa wewnętrznego.

Zgodnie z literą putinowskiego dekretu z 30 kwietnia 2016 roku „O Federalnoj Sluzbe Wojsk Nacionalnoj Gwardii Rossijskoj Federacji” nadrzędnym celem działalności Federalnej Służby Gwardii Narodowej jest,zagwarantowanie bezpieczeństwa państwowego oraz publicznego, jak również w celu ochrony praw i wolności człowieka i obywatela”. Co charakterystyczne wyznaczone zadania oraz przypisane pełnomocnictwa Federalna Służba Gwardii Narodowej realizuje jako federalny organ władzy wykonawczej Federacji Rosjskiej.

Powstała na bazie wojsk wewnętrznych Ministerstwa Spraw Wewnętrznych Federacji Rosyjskiej Federalna Służba Gwardii Narodowej wraz z Federalną Służbą Bezpieczeństwa, Służbą Wywiadu Zagranicznego, Federalną Służbą Ochrony, Federalną Służbą Kontroli Technicznej i Transportu, Żandarmerią Wojskową, Służbą Programów Specjalnych funkcjonującą przy prezydencie Federacji Rosyjskiej zalicza się do sił i środków wymaganych do zagwarantowania bezpieczeństwa, czyli do tzw. specsłużb. Na mocy podpisanego 5 kwietnia 2016 prezydenckiego dekretu bazę strukturalną Federalnej Służby Gwardii Narodowej stanowią wojska narodowej gwardii Federacji Rosyjskiej, które powstały z przekształcenia wojsk wewnętrznyh Ministerstwa Spraw Wewnętrznych Federacji Rosyjskiej, co doprowadziło do znacznego ograniczenia zakresu kompetencji rosyjskiego MSW. W struktury Federalnej Służby Gwardii Narodowej zostały włączone m. in. organy zarządzające i podjednostki Ministerstwa Spraw Wewnętrznych, wykonujące państwową kontrolę nad przestrzeganiem rosyjskiego prawodawstwa w sferze obrotu bronią i w sferze działalności prywatnych firm ochroniarskich. Ministerstwu Spraw Wewnętrznych zostały podporządkowane również służby ochrony obiektów wszystkich form własności, apartamentów, jak również miejsc przechowania mienia osobistego obywateli. W struktury Federalnej Służby Gwardii Narodowej zostały włączone również Centrum Operacji Specjalnych ds. Ochrony Prywatnej Ministerstwa Spraw Wewnętrznych Federacji Rosyjskiej, oraz Specjalne Oddziały Szybkiego Reagowania Terytorialnych Organów Ministerstwa Spraw Wewnętrznych. W tym Oddziały Mobilne Specjalnego Przeznaczenia Terytorialnych Organów Ministerstwa Spraw Wewnętrznych (OMON), Centrum Sił Specjalanych Szybkiego 
Reagowania i jednostek lotnictwa Ministerstwa Spraw Wewnętrznych, Specjalne Oddziały Szybkiego Reagowania (SOBR). Zadekretowanym, formalnym celem zintegrowanych działań Federalnej Służby Gwardii Narodowej jest „wypracowywanie i realizacja polityki państwowej oraz normatywno-prawnych regulacji w sferze działalności wojsk Gwardii Narodowej”, a także „w sferze obrotu bronią, działalności prywatnych firm ochroniarskich oraz obrony pozaresortowej”, co stanowi egzemplifikację niepewności władz co do stabilności i integralności systemu politycznego Federacji Rosyjskiej.

Prezydencki dekret nr 157 z kwietnia 2016 roku oraz dekret nr 158 z 5 kwietnia 2016 „O Direktore Federalnoj Sluzby Wojsk Nacjonalnoj Gwardii Rossijskoj Federacji - glawnokomandyjuszem wojskami Nacjonalnoj Gwardii Rossijskoj Federacji”- głównodowodzącym wojsk Rosyjskiej Gwardii Narodowej określają również pozycję i kompetencje dowodzącego Federalną Służbą Gwardii Narodowej. Na czele nowo powołanej specsłużby stoi dyrektor, na którego stanowisko został powołany generał Wiktor Zołotow - zaufany, lojalny współpracownik Władimira Putina, który w przeszłości stał na czele Służby Ochrony Prezydenta. Zgodnie z dekretem nr 158 Dyrektor Federalnej Służby Gwardii Narodowej jest jednocześnie głównodowodzącym wojsk Rosgwardii. W związku z utworzeniem nowej formacji odpowiedzialnej za zapewnienie bezpieczeństwa wewnętrznego zmian dokonano w składzie Rady Bezpieczeństwa Federacji Rosyjskiej. Na mocy znowelizowanego 5 kwietnia 2016 roku dekretu prezydenckiego N715 z 2012 "O wniesieni izmenienja w sostaw Sowieta Biesopasnosti Rossijskoj Federacji” stałym członkiem Rady został dyrektor Federalnej Służby Gwardii Narodowej, którego funkcje obecnie pełni Wiktor Zołotow.

Zgodnie z literą kwietniowego dekretu nr 157, który powołał do istnienia nową specsłużbę, Federalna Służba Gwardii Narodowej jest formacją bezpośrednio podporządkowaną prezydentowi Federacji Rosyjskiej, a do jej głównych, enumerowanych w dekrecie zadań Federalnej Służby Gwardii Narodowej należy:

- Współuczestnictwo razem z innymi rosyjskimi organami ścigania w ochronie porządku i bezpieczeństwa publicznego,

- Współuczestnictwo w walce z terroryzmem, ekstremizmem oraz zorganizowaną przestępczością,

- Uczestnictwo w terytorialnej obronie Federacji Rosyjskiej,

- Ochrona ważnych obiektów państwowych i ładunków specjalnych zgodnie z listą zatwierdzoną przez rząd Federacji Rosyjskiej,

- Pomoc pogranicznym organom Federalnej Służby Bezpieczeństwa w ochronie granicy państwowej Federacji Rosyjskiej, 
- Wykonywanie państwowej kontroli nad przestrzeganiem prawodawstwa Federacji Rosyjskiej w dziedzinie obrotu bronią, działalności prywatnych przedsiębiorstw ochroniarskich oraz ochrony pozaresortowej.

Zgodnie z dekretem nr 510 z 30 września 2016, wyżej wymienione zadania Rosgwardia realizuje przy wykorzystaniu szerokiej gamy uprawnień. Federalna Służba Gwardii Narodowej może w uzasadnionych okolicznościach żądać od władz federalnych i lokalnych dokumentów z informacjami dotyczącymi urzędników oraz obywateli, a także tych, które są wymagane do podjęcia decyzji w kwestiach związanych z funkcjonowaniem Rosgwardii oraz mieszczą się w zakresie jej kompetencji. Tym samym Federalna Służba Gwardii Narodowej jako struktura awaryjna dysponuje prawem zawieszenia, a w sytuacjach nadzwyczajnych ograniczenia korzystania z sieci łączności, środków komunikacyjnych. Z opublikowanej przez rosyjską agencję prasową TASS informacji Russia's National Guard to interact with counterparts from other countries (2016) wynika, iż w kontekście uzasadnionego prawnie nieograniczonego dostępu do środków łączności oraz dysponowania możliwością ustanowienia ograniczeń w ich użytkowaniu funkcjonariuszom Federalnej Służby Gwardii Narodowej przysługuje pierwszeństwo wykorzystania sieci oraz środków łączności.

Jako swoistej armii wewnętrznej Rosgwardii ustawodawca udzielił prawa użycia broni w tłumie. Użycie broni w tłumie jest uzasadnione, gdy jest to konieczne do uniknięcia ataku terrorystycznego, uwolnienia zakładników, rozbrojenia grupy napastników lub w sytuacji zbrojnej napaści na ważne obiekty państwowe lub ładunki. Pomimo że Federalna Służba Gwardii Narodowej jest strukturą zoientowaną na zabezpieczanie porządku wewnętrznego, to nie posiada przypisanych uprawnień zezwalającyh strukturze na prowadzenie śledztw w terenie. Prezydencki dekret nr 157 powołujący do istnienia Federalną Służbę Gwardii Narodowej nie przewiduje utworzenia wewnątrz Rosgwardii wyspecjalizowanych struktur operacyjnych i śledczych. Niemniej jednak - jak zauważa Ekaterina Zapara (2016) - kompetencje nowo utworzonej specsłużby charakteryzuje dalekoidąca kompleksowość oraz znaczny zasięg, czego przykładem jest możliwość realizacji prawa kontroli pojazdów obywateli.

$\mathrm{Na}$ mocy prezydenckiego dekretu nr 510 z dnia 30 września 2016 roku nowa formacja dysponuje prawem wyłączenia $z$ użytku publicznego obszaru objętego zamieszkami, co umożliwia ich pełną kontrolę oraz pacyfikację. Ponadto wrześniowy dekret sankcjonuje możliwość wykorzystania przez funkcjonariuszy Rosgwardii prywatnych pojazdów obywateli w celu dostania się na miejsce popeł- 
nienia przestępstwa lub ścigania sprawców, jak również przyznaje strukturze prawo do uzasadnionego okolicznościami dostępu do zasobów informacyjnych.

Ustanowioną w dekrecie nr 510 prawem Federalnej Służby Gwardii Narodowej - potwierdzającym szeroki zakres jej enumerowanych kompetencji - jest możliwość objęcia pełną kontrolą sieci komunikacyjnych oraz środków łączności w warunkach realizacji zadań operacyjnych. Rosgwardii przysługuje również prawo do przeszukiwania prywatnych mieszkań obywateli, co do których istnieje wystarczająca podstawa do podejrzewania osoby o popełnienie przestępstwa. Ponadto dekret nr 510 nakłada na Federalną Służbę Gwardii Narodowej obowiązek prowadzenia obowiązkowej, państwowej rejestracji daktyloskopijnej żołnierzy oraz pracowników wojsk Rosgwardii.

W kontekście wzmacniania antyzachodniej retoryki Władimira Putina Federalna Służba Gwardii Narodowej jawi się jako struktura uczestnicząca w zakresie swoich kompetencji w wojnie informacyjnej przeciwko Federacji Rosyjskiej. W sferze formalnej i w zakresie przysługujących Rosgwardii uprawnień oraz zgodnie z rosyjskim ustawodawstwem formacja dysponuje prawem podpisywania umów międzynarodowych oraz nawiązywania współpracy z organami innych państw oraz organizacjami międzynarodowymi. W kontekście międzynarodowej aktywności nowej formacji do zadań Federalnej Służby Gwardii Nrodowej należy zabezpieczanie bezpieczeństwa informacyjnego Rosji oraz gromadzenie informacji w celu zwalczania terroryzmu i ekstremizmu. Pomimo że na mocy dekretu prezydenckiego nr 157 Federalna Służba Gwardii Narodowej jest siłą uczestniczącą $\mathrm{w}$ walce $\mathrm{z}$ terroryzmem, to jej rzeczywista funkcja jest zredukowana do siłowego wspierania działań antyterrorystycznych prowadzonych przez Federalną Służbę Bezpieczeństwa. Utworzenie nowej formacji współodpowiedzialnej za ochronę bezpieczeństwa państwowego oraz publicznego znacząco redukuje znaczenie policyjnego potencjału państwa rosyjskiego na rzecz wzmocnienia funkcji porządkująco-politycznych rosyjskiego aparatu państwowego, co jest szczególnie istotne w kontekście zbliżającej się elekcji prezydenckiej w 2018 roku.

Przekształcenie wojsk wewnętrznych Ministerstwa Spraw Wewnętrznych Federacji Rosyjskiej i utworzenie na ich kanwie Federalnej Służby Gwardii Narodowej jest elementem szerszej strategii umacniania monopolu władzy obozu prezydenckiego, którego antyzachodnia, konspirologiczna wizja świata oraz kondycji Rosji jako unikatowej, samoistnej, odrębnej od Zachodu cywilizacji wspiera mocno zakorzeniony w rosyjskiej tradycji autorytet polityczny specsłużb jako filaru gwarantującego stabilizację ośrodka władzy. Tym samym powołanie specsłużby bezpośrednio podległej prezydentowi Federacji Rosyjskiej jest 
elementem - przenośnikiem rosyjskiej tradycji silnej pozycji struktur siłowych w rosyjskim aparacie państwowym.

Obserwowany od początku prezydentury Władimira Putina wzrost autorytetu, lojalności oraz zaufania samego prezydenta wobec służb specjalnych określa charakter procesu FSB-fikacji władzy w Rosji. Nie ulega wątpliwości, iż priorytetem polityki Władimira Putina jako kadrowego funkcjonariusza KGB wobec środowisk siłowych była i jest rehabilitacja pozytywnego wizerunku służb specjalnych jako struktury o politycznym znaczeniu oraz aspiracjach wykraczających poza wykonywanie funkcji operacyjnych i śledczych.

W perspektywie zbliżających się wyborów prezydenckich w 2018 roku istotne znaczenie przedstawiają słowa dyrektora Federalnej Służby Gwardii Narodowej Wiktora Zołotowa. Jak podkreśla Julia Gornostajewa (2016), Zołotow określa ewolucyjny proces formowania struktur oraz określania zadań nowo powstałej służby. Według Wiktora Zołotowa na proces kształtowania się struktur Rosgwardii i jej zadań składają się następujące po sobie trzy podstawowe stadia:

1. Przekształcenie wojsk wewnętrznych w wojska gwardii narodowej,

2. Opracowanie struktury organizacyjnej i dyspozycja zadań,

3. Zakończenie działań organizacyjnych związanych $\mathrm{z}$ formowaniem Federalnej Służby Gwardii Narodowej i początek realizacji powierzonych Rosgwardii zadań.

Sfinalizowanie procesu formowania struktury organizacyjnej Federalnej Gwardii Narodowej planowane na rok 2018 jest istotnym przyczynkiem do interpretowania charakteru prezydenckiej specsłużby jako narzędzia gwarantującego Władimirowi Putinowi reelekcję prezydencką, a tym samym zachowanie kontynuacji idei samodzierżawnej, bizantyjskiej, sakralizowanej władzy, którą zabezpiecza autorytet struktur siłowych.

W perspektywie zbliżającej się elekcji prezydenckiej oraz w dynamice pozimnowojennej, wielobiegunowej rzeczywistości międzynarodowej utworzenie Federalnej Służby Gwardii Narodowej jest interpretowane jako adekwatna, systemowa odpowiedź rosyjska na nowoczesne zagrożenia wynikające z globalnego charakteru konfliktów międzynarodowych oraz na potencjalne niebezpieczeństwo marginalizacji Rosji oraz rosyjskiego interesu narodowego przez dążący do uplasowania się na pozycji hegemona, zarówno w sferze normatywnej, jak i politycznej, Zachód. Unifikujący neokolonializm Zachodu, objawiający się $\mathrm{w}$ nieusankcjonowanych ingerencjach $\mathrm{w}$ wewnętrzne polityki państw, stanowi istotne zagrożenie dla interesów Rosji w przestrzeni postradzieckiej, uważanej za sferę jej naturalnych wpływów, jak również stwarza niebezpieczeństwo pod- 
porządkowania integralnego, unikatowego charakteru rosyjskiej tożsamości cywilizacyjno-kulturowej hegemonii liberalnego Zachodu. W tym kontekście Federalna Służba Gwardii Narodowej stanowi strategiczne narzędzie chroniące stabilność rosyjskiego reżimu politycznego oraz ubezpieczające cywilizacyjną samoistność Rosji przed potencjalną destabilizacją oraz inkorporacją rosyjskości w sferę wpływów Zachodu, Powołanie do istnienia nowej specsłużby o znacznym potencjale polityczno-ideologicznym konsoliduje negatywny wizerunek Zachodu jako cywilizacji dążącej do zawłaszczenia heteronomicznego charakteru świata pod pozorem transferu uniwersalnych wartości liberalno-demokracznych poprzez inicjowanie tzw. „kolorowych rewolucji” w państwach nienależących do kręgu cywilizacji zachodniej. Dowodem na popularność i społeczną akceptację polityki Władimira Putina, a więc również działań skoncentrowanych na fortyfikacji reżimu przy wykorzystaniu potencjału specsłużb jest zdecydowanie pozytywna ocena kursu politycznego Rosji. Według badań oceny obecnej sytuacji w Rosji przeprowadzonych przez Centrum Levady (2016) 50\% respondentów pozytywnie ocenia politykę Rosji, co jest skorelowane z niezmiennie wysokim wskaźnikiem społecznej aprobaty dla prezydentury Władimira Putina, który we wrześniu 2016 roku wyniósł 82\%. Oba wskaźniki manifestują społeczną aprobatę dla antyzachodniego trendu retoryki putinowskiej oraz obrazują, jak istotną rolę może odegrać w przyszłości Federalna Służba Gwardii Narodowej jako narzędzie konfronacji specyfiki rosyjskiej rzeczywistości społeczno-politycznej z zachodnim typem kulturowo-cywilizacyjnym. Niemniej jednak wysokie wskaźniki poparcia dla władzy prezydenta Władimira Putina nie stanowią wystarczającej przesłanki do zaprzestania starań na rzecz stabilizacji reżimu. Niepokój władz na Kremlu budzi niekorzystna sytuacja gospodarki w Rosji, która - pogrążona w stagnacji, może odegrać rolę katalizatora erupcji społecznego niezadowolenia, a w konsekwencji przyczynić się do spadku poparcia dla prezydentury i obniżyć szanse reelekcji Władimira Putina.

Tworząc nową specsłużbę, której zadania koncentrują się na ochronie porządku wewnętrznego, a w praktyce służą realizacji strategii efektywnego zarządzania zamieszkami opocycjonistów, Putin zyskuje narzędzie konsolidacji podstaw legitymizacji systemu. W kontekście problematyzacji podstaw putinowskiej antyzachodniej retoryki oraz apologii służb specjalnych jako zaplecza władzy Federalna Służba Gwardii Narodowej jawi się jako struktura siłowa, która pełni funkcję ochronną wobec samoistności rosyjskiej oraz zabezpiecza przed próbami ingerencji oraz oddziaływania hegemonicznego Zachodu na wewnętrzną politykę Rosji, który aspirując do zmiany reżimu politycznego, 
finalnie oczekuje włączenia Rosji w sferę peryferii Zachodu. Rosja jako peryferie, cywilizacja podporządkowana zachodniemu uniwersalizmowi, na skutek westernizacji rosyjskich tradycji w duchu zachodniej aksjologii i standardów liberalnej demokracji traci podmiotowość jako partner w stosunkach międzynarodowych. Militaryzacja antyzachodniej retoryki, ekspozycja czynnika siłowego jako zaplecza gwarantującego nienaruszalność systemu jest charakterystyczną cechą postępującej od 1999 roku FSB-fikcji władzy w Rosji.

Działalność Rosgwardii koncentruje się na kwestiach związanych z bezpieczeństwem wewnątrz państwa. Niemniej jednak nowo powstała służba jako gwarant przetrwania reżimu dysponuje możliwością tłumienia nieuprawnionych z perspektywy władzy rosyjskiej działań masowych organizowanych przez opozycję, jak również ma prawo uczestnictwa w działaniach antyterrorystycznych poza granicami Federacji Rosyjskiej. Licencja na prowadzenie działań poza granicami Rosji świadczy o możliwości - uzasadnionych z perspektywy władzy w Rosji - ingerencji na obszarach, w których odnotowano zagrożenie żywotnych rosyjskich interesów oraz rosyjskiego statusu quo. Według Russia Today National Guard to get license for peacekeeping operations abroad (2016) tak rozumiane umiędzynarodowienie działalności służby o zadekretowanym charakterze wewnętrznym czyni z Federalnej Służby Gwardii Narodowej podmiot, któremu ustawodawca umożliwił angażowanie się w szereg operacji o charakterze międzynarodowym. Wykorzystanie potencjału Federalnej Służby Gwardii Narodowej w misjach zagranicznych jest obecnie jedynie teoretyczną możliwością, gdyż obowiązujące w Federacji Rosyjskiej przepisy prawne nie sankcjonują takiej ewentualności.

Utworzenie Federalnej Służby Gwardii Narodowej podporządkowanej bezpośrednio prezydentowi Federacji Rosyjskiej Władimirowi Putinowi jest jednym z elementów strategii prewencji w walce zarówno istniejącymi, jak i przyszłymi zagrożeniami wewnętrznej integralności Rosji oraz walki z punktami zapalnymi terroryzmu międzynarodowego na Południowym Kaukazie oraz w Azji Centralnej. Jak podkreśla Walters (2016), Federalna Służba Gwardii Narodowej jest strukturą powołaną do reagowania na zagrożenia integralności Rosji oraz porządku wewnętrznego; jednym z głównych celów działania Rosgwardii jest przeciwdziałanie rozprzestrzenianiu się międzynarodowego terroryzmu na terytorium Federacji Rosyjskiej. Funkcjonowanie struktury zabezpieczającej porządek wewnętrzny, a w domyśle gwarntującej stabilność putinowskiego reżimu, budzi szereg pytań i kontrowersji. Utworzenie nowej służby odpowiedzialnej za wzmocnienie reżimu putinowskiego oraz określonej geopolitycznej wizji Rosji stanowi manifestację 
eskalacji pierwiastka bezpieczeństwa w antyzachodniej retoryce Władimira Putina.Według Kiriła Rogowa (2016) utworzenie Federalnej Służby Gwardii Narodowej jest najbardziej radykalną zmianą w krajobrazie rosyjskich organów ścigania, jaka nastąpiła w ciągu ostatniego dziesięciolecia zaś wojska Rosgwardii jako nowa armia wewnętrzna są strukturą, której przysługuje szeroka gama środków - w tym funkcja ochrony porządku publicznego. Implikuje to możliwość pacyfikacji oraz kontroli ewentualnych niepokojów społecznych w celu zabezpieczenia reżimu przed destabilizacją. Niemniej jednak utrata uprawnień i pełnomocnictw Ministerstwa Spraw Wewnętrznych Federacji Rosyjskiej na rzecz nowo powstałej służby ochrony porządku publicznego jest zdarzeniem bezprecedensowym w rosyjskiej historii, a zredukowane pełnomocnictwa Ministerstwa Spraw Wewnętrznych zbliżają status urzędu do scentralizowanego systemu policji miejskiej.

Powołanie podporządkowanej prezydentowi Federacji Rosyjskiej specsłużby jest instytucjonalnym przejawem wzrastających obaw Kremla przed potencjalną destabilizacją reżimu politycznego w Rosji. Konieczność inwestycji w lojalny potencjał służb specjalnych jest wpisana w tradycję rosyjskiej kultury politycznej, której rdzeniem jest koncepcja wertykalnej struktury władzy bazującej na lojalności środowisk siłowych. Zaufanie władz względem potencjału służb specjalnych jest integralnym elementem rosyjskiej kultury politycznej, której esencja zawiera się w strategii komasacji reżimu politycznego oraz zabezpieczenia jego podstaw przed chaosem i destabilizacją. W tym kontekście powstanie Federalnej Służby Gwardii Narodowej stanowi odwołanie do tradycyjnej legitymizacji władzy rosyjskiej, która wykorzystuje autorytet środowisk siłowych do fortyfikacji stabilności fundamentów rosyjskiego systemu politycznego. Jako armia wewnętrzna Federalna Służba Gwardii Narodowej jest strukturą o charakterze awaryjnym, która została powołana na wypadek potencjalnego przewrotu politycznego. Nie ulega kwestii, iż Federlna Służba Gwardii Narodowej to dostosowana do warunków i wyzwań XXI wieku opricznina, która pełni funkcję armii, jak również służby bezpieczeństwa działającej nie tylko wewnątrz Federacji Rosyjskiej, lecz również w przestrzeni międzynarodowej.

Plan umiędzynarodowienia działalności Federalnej Służby Gwardii Narodowej służy uzasadnianiu wpływów rosyjskich w obszarach potencjalnej ingerencji i w dalszym ciągu pozostaje kwestią otwartą na regulacje. Niemniej jednak Rosgwardia jako narzędzie oddziaływania rosyjskiego w przestrzeni zarówno wewnętrznej, jak i międzynarodowej koncentruje się na nawiązaniu współpracy z właściwymi organami innych państw na bazie relacji szkoleniowej, jak również 
na prowadzeniu działalności związanej z realizacją priorytetów rosyjskiej polityki zagranicznej i rosyjskiej racji stanu. Według informacji Crimean News Agency Russia deploys barrier squad of National Guard in Donbas (2016) pierwszym dowodem na internacjonalizację charakteru działań Federalnej Służby Gwardii Narodowej była obecność w maju 2016 roku proukraińskich oddziałów Gwardii Narodowej w Donbasie w celu zapobieżenia dezercji noworosyjskich żołnierzy

Reorganizacja służb bezpieczeństwa, włączenie Federalnej Służby Obrotu Narkotykami oraz Fedralnej Służby Migracyjnej do struktur Ministerstwa Spraw Wewnętrznych oraz utworzenie Federalnej Służby Gwardii Narodowej ukazuje jak istotne we współczesnej polityce rosyjskiej jest wsparcie środowiska służb specjalnych jako gwaranta stabilności reżimu politycznego oraz utrzymania monopolu na sprawowanie władzy, której podstawę stanowi wertykalizm oraz centralizacja uzasadniana specyficzną tradycją rosyjskiej państwowości, a także szczególną esencją rosyjskiej rzeczywistości politycznej zorientowanej wokół realizacji rosyjskiego interesu narodowego.

Swoista zefesbefikowana putinokracja, której konserwatywny, nacjonalistyczny komponent przeżywa swój renesans od 2012 roku, jest systemem odzwierciedlającym antyzachodni, konspirologiczny charakter retoryki Władimira Putina. W kontekście kreacji wizji Rosji - oblężonej twierdzy kluczowe jest wykorzystanie wsparcia służb specjalnych, które podzielają antyzachodni, konspirologiczny obraz świata władz na Kremlu, jak również stanowią najbardziej rozbudowane zaplecze informacyjne prezydenta Federacji Rosyjskiej, zgodnie z którym Zachód to wróg - „nie-my”, zaś Rosja to wyjątkowa cywilizacyjna jednia, której dynamiką rozwojową, polityczno-społeczną oraz kulturową rządzą odmienne od zachodnich prawa i wartości.

Utworzenie Federalnej Służby Gwardii Narodowej, podporządkowanej bezpośrednio prezydentowi Rosji, należy intepretować jako zabieg zorientowany na utrzymanie strategicznej stabilności reżimu władzy w obliczu zbliżających się wyborów prezydenckich w 2018 roku. W dobie kryzysu gospodarczego formuła legitymizacji działań władzy, której podstawę stanowiło dążenie do stabilizacji i polepszenia warunków bytowych obywateli Federacji Rosyjskiej, uległa wyczerpaniu, toteż władza poszukuje skutecznych, instytucjonalnych sposobów na umocnienie poparcia wobec postulatu reelekcji Władimira Putina oraz zabezpieczenia fundamentów rosyjskiego wertykalizmu z dominującą pozycją środowisk siłowych.

Jednocześnie wojska Rosgwardii pełnią funkcję jednego z głównych zabezpieczeń systemu przed potencjalną destabilizacją oraz stanowią rosyjski 
wariant odpowiedzi na wschodnią ekspansję Sojuszu Półnoatlantyckiego, która jest postrzegana jako zagrożenie dla integralności Rosji, oraz tzw. rosyjskiego świata, w którego skład wchodzą państwa postradzieckie połączone wspólnotą cywilizacyjną i kulturową.

Utworzenie Federalnej Służby Gwardii Narodowej wpisuje się w tradycję legitymizacji władzy w Rosji przez odwołanie się do autorytetu środowisk siłowych. W kontekście procesów westernizacji nowa służba stanowi narzędzie walki z upowszechnianiem w przestrzeni postradzieckiej „kolorowych” rewolucji, które transferują ideały krańcowo sprzeczne ze specyfiką historyczno-kulturową obszaru postsowieckiego. Powołanie nowej służby należy więc interpretować jako element szerszej strategii ubezpieczania reżimu przed wpływem „obcej”, zewnętrznej wobec siłowej tradycji rosyjskiej państwowości cywilizacji Zachodu, co wpisuje się w strategię FSB-fikowania władzy w Rosji.

\section{BibLIOGRAFIA:}

Borogan, I., Sołdatow, A. (2010). The New Nobility: The Restoration of Russia's Security State and the Enduring Legacy of the KGB. Nowy Jork: Public Affairs.

Centrum Jurija Levady. (2016). Ocenka tekuszego polożenja diel w stranie. Pobrane z: http://www.levada.ru/indikatory/polozhenie-del-v-strane/.

Chałsowski, E. (2016). Russia and the West Collide. Pobrane z: https://www.stratfor.com/ analysis/origins-conflict.

Fokina, A.W. (2014). K woprosu o russkom mire. Pobrane z: http://filos.univ-orel. ru/_media/issue/1/2014-01-04.pdf

Gornostajewa, J. (2016). Formowanie Rosgwardii zakonczitsa w 2018 godu. Pobrane z: http://izvestia.ru/news/625000.

Menkiszak, M. (red.).(2015). Późny Putin. Koniec rozwoju, koniec stabilności. Warszawa: Ośrodek Studiów Wschodnich im. Marka Karpia.

National Guard to get license for peacekeeping operations abroad. Pobrane z: https:// www.rt.com/politics/339290-russian-national-guard-to-get/,

Orlowa, K. (2016). The Siloviki Coup in Russia. Pobrane z: http://www.the-american-interest.com/2016/09/21/the-siloviki-coup-in-russia/.

Putin, W. (2016). Woprosy Federalnoj Sluzby Wojsk Nacjonalnoj Gwardii Rossijskoj Federacji ot 5.04.2016, no. 157. Pobrane z: http://publication.pravo.gov.ru/Document/ View/0001201604050058? index $=1$ \&rangeSize $=1$.

Putin, W. (2016). O Direktore Federalnoj Sluzby Wojsk Nacjonalnoj Gwardii Rossijskoj Federcji - glawnokomandujuszem Wojskami Nacjonalnoj Gwardii Rossijskoj Federacji ot 5.04.2016 no. 158. Pobrane z: http://publication.pravo.gov.ru/Document/ View/0001201604050055. 
Putin, W. (2016). O Federalnoj Sluzbe Wojsk Nacjonalnoj Gwardii Rossijskoj Federacji ot 30.09.2016 no. 510. Pobrane z: http://publication.pravo.gov.ru/Document/ View/0001201610040002? index $=0$ \&rangeSize $=1$.

Putin, W. (2016). O wniesieni izmienienja w sostaw Sowieta Biezopasnosti Rosssijskoj Federacji, utwierżdennyj Ukazom Prezidienta Rossijskoj Federacji ot 25.05.2012 g. N 715. Pobrane z: http://kremlin.ru/acts/bank/40684.

Renz, B. (2007). The Siloviki in Russian Politics: Political Strategy or a Product of the System?. Russian Analytical Digest, 17, 3-4.

Rogow, K. (2016). Eskalacija biezopasnosti: zaczem Putinu potrebowalas swoja armija. Pobrane z: http://www.rbc.ru/opinions/society/08/04/2016/5707a4129a79477ed499665e.

Russia deploys barrier squad of National Guard in Donbas. Pobrane z: http://qha.com. ua/en/society/russia-deploys-barrier-squad-of-national-guard-in-donbas/137120/

Russia's National Guard to interact with counterparts from other countries. Pobrane z: http://tass.ru/en/politics/868828.

Sakwa, R. (2008). Russian Politics and Society. Londyn, Nowy Jork: Routledge Taylor\&Francis Group.

Tkaczenko, S. (2011). Informacjonnaja wojna protiw Rossiji .Sankt Petersburg, Moskwa: Piter

Walters, G. (2016). Putin's New National Guard Strengthens His Grip on Security as Russian Economy Falters. Pobrane z:. https://news.vice.com/article/putins-newnational-guard-strengthens-his-grip-on-security-as-russian-economy-falters.

Zapara, E. (2016). Dumskij komitet odobril primienienie Rosgwardiej orużenja w tolpie. Pobrane z: https://meduza.io/en/news/2016/06/20/lawmakers-approve-amendments-allowing-russia-s-new-national-guard-to-fire-into-crowds-and-search-cars.

Żochowski, P. (2016). Rosja: Gwardia Narodowa, czyli armia wewnętrzna wkracza do gry. Pobrane z: http://www.osw.waw.pl/pl/publikacje/analizy/2016-04-06/rosjagwardia-narodowa-czyli-armia-wewnetrzna-wkracza-do-gry. 